\title{
MARINE RESERVOIR AGES IN NORTHERN SENEGAL AND MAURITANIA COASTAL WATERS
}

\author{
Maurice Ndeye \\ Laboratoire Carbone 14, IFAN, Université Cheikh Anta Diop de Dakar, Senegal. Email: mndeye@ucad.sn.
}

ABSTRACT. In order to estimate the modern reservoir age of the seawater $(R)$ and the corresponding local offset from the global marine radiocarbon calibration curve $(\Delta \mathrm{R})$ for coastal sites of Senegal and Mauritania, we analyzed pre-bomb mollusk shells collected between AD 1837 and 1945. In total, 27 shell samples were measured, including 19 from Senegal and 8 from Mauritania. The results for Senegal for the weighted mean of $R$ is $511 \pm 50 \mathrm{BP}$ and $\Delta \mathrm{R}$ is $176 \pm 15 \mathrm{BP}$; for Mauritania, $R$ is $421 \pm 15 \mathrm{BP}$ and $\Delta \mathrm{R}$ is $71 \pm 13 \mathrm{BP}$. While these values indicate a significant difference from the global mean value of $R$ for Senegal, the $R$ value for coastal Mauritania is close to the average ocean value $R$ of $\sim 400 \mathrm{yr}$ (Stuiver and Braziunas 1993).

\section{INTRODUCTION}

Calibration is essential for interpreting radiocarbon dates, and this is particularly true for studies comparing historical or climatic records. Similarly, the use of ${ }^{14} \mathrm{C}$ ages from samples that grow in marine environments (i.e. mollusks, fish bones, etc.) requires special consideration. Mixing of water masses (i.e. during upwelling) may dilute the amount of ${ }^{14} \mathrm{C}$ in the water. Marine organisms that absorb their carbon from dissolved inorganic carbon (DIC) typically have relatively older ages due to the dilution effect in the ocean, as compared to atmospheric ages. Models of exchange between the atmosphere and the ocean have been proposed for surface waters $(0-75 \mathrm{~m})$, thermocline waters (75-1000 m), and deep waters (1000-3800 m) (Stuiver and Braziunas 1993). From the model of surface waters, verified by ${ }^{14} \mathrm{C}$ dates on shells of known ages, one can calculate a global mean value for pre-AD 1950 marine reservoir age correction $\mathrm{R}(\mathrm{t})$ of $400 \mathrm{yr}$. Some laboratories publish ${ }^{14} \mathrm{C}$ ages without reservoir effect corrections; however, this approximation is not sufficient for archaeological applications that require calibration using programs such as CALIB (Reimer and Reimer 2001). It has been demonstrated that the variability of reservoir ages at a particular site depends on oceanic water mass circulation and mixing (e.g. Siani et al. 2000; Southon et al. 2002). In upwelling zones, for instance, mixing of deep waters with surface waters produces important local reservoir effects, with $\Delta \mathrm{R}$ values of several hundred years or more. Unfortunately, compilations of $\Delta \mathrm{R}$ on a global scale — by Stuiver et al. (1986), Stuiver and Braziunas (1993), and more recently the marine reservoir correction database online by Reimer and Reimer (2001, 2006) — do not give values for most of the African coast, with the exception of a few values for northern Africa and South Africa. This study seeks to fill that gap, at least in part as it focuses on the estimation of the mean value for the reservoir effect for coastal Senegal and Mauritania, western Africa. It has been suggested that the reservoir effect in this part of Africa could be high because it should be affected by upwelling phenomena (Goodfriend and Flessa 1997). This study area extends from Port Etiénne $\left(21^{\circ} 01^{\prime} \mathrm{N}\right.$, $\left.17^{\circ} 02^{\prime} \mathrm{W}\right)$ (coastal Mauritania) in the north to Rufisque $\left(14^{\circ} 42^{\prime} \mathrm{N}, 17^{\circ} 15^{\prime} \mathrm{W}\right)$ on the Cap-Vert (Cape Verde) peninsula (coastal Senegal). ${ }^{14} \mathrm{C}$ dates are calculated on pre-AD 1950 gastropods from which are calculated reservoir ages. The results presented here are the first attempt to evaluate the reservoir ages of the surface waters of the western Atlantic Ocean, which remained relatively unknown until now.

\section{MATERIAL AND METHODS}

Some 27 samples of bivalve shells were obtained from the collection of the archaeology laboratory at IFAN, Université Cheikh Anta Diop (Dakar, Senegal) and at the Muséum National d'Histoire Naturelle (Paris, France). These samples were collected between AD 1937-1945 by various scientists and some amateurs doing fieldwork on coastal sites in Senegal and Mauritania. Museum num- 
bers were unavailable for some of the samples; however, reference information including the name of the collector, the nature the material, the date of collection, etc. (cf. Tables 1 and 2) are given for each sample. Figure 1 shows the approximate location where samples were collected.

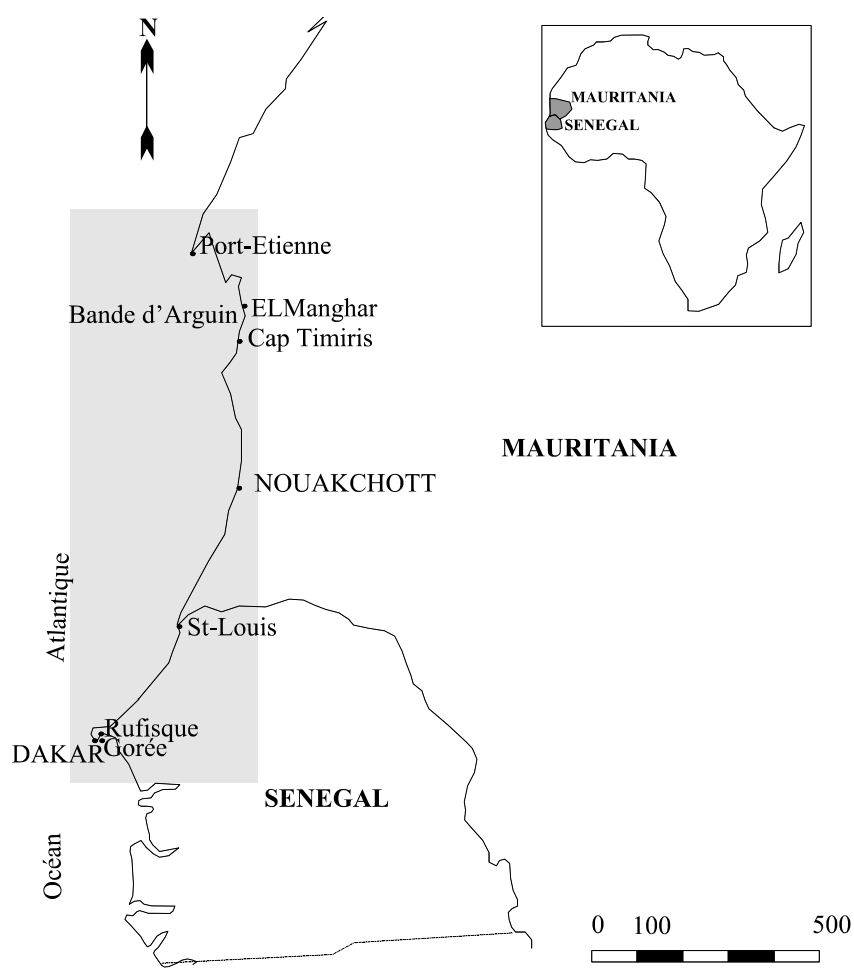

Figure 1 Study area (shaded) showing location of known marine shells collected for this research. Scale in kilometers.

${ }^{14} \mathrm{C}$ dates that were suspected to be too old were omitted from the analysis (e.g. AA-70006, AA70010, AA-70011, AA-70018, AA-70020, and AA-70022). The criteria for omitting samples used here consists of comparing ${ }^{14} \mathrm{C}$ values from the same site at the same time of collection. Series of multiple samples from the same site are compared to each other (Yoneda et al. 2000).

Sample Gif-12173 was analyzed by a proportional counter at the LSCE laboratory. Five additional accelerator mass spectrometry (AMS) samples were analyzed at ARTEMIS, located in the Laboratoire de Mesure du Carbone 14 (Saclay, France).

Mollusk shells were treated in nitric acid $(2 \mathrm{~mL}, 0.01 \mathrm{M})$ for $15 \mathrm{~min}$ and subsequently submitted to ultrasound for 10 seconds. $\mathrm{CO}_{2}$ was obtained from the shell via a reaction with orthophosphoric acid at $60{ }^{\circ} \mathrm{C}$, each time using an amount of shell sufficient to produce a volume of $\mathrm{CO}_{2}$ containing $\sim 1 \mathrm{mg}$ of carbon. The $\mathrm{CO}_{2}$ was graphitized at $575{ }^{\circ} \mathrm{C}$ using $\mathrm{H}_{2}$ in the presence of iron powder at a weight about 3 times the mass expected for carbon. The resulting graphite was then pressed into an AMS target.

A comparison was made of sequentially measured beam intensities of ${ }^{14} \mathrm{C},{ }^{13} \mathrm{C}$, and ${ }^{12} \mathrm{C}$ for each sample and those of the $\mathrm{CO}_{2}$ standards prepared from the oxalic acid standard HOxI. The percent of modern carbon (pMC) was then calculated and normalized to a $\delta^{13} \mathrm{C}$ of $-25 \%$. ${ }^{14} \mathrm{C}$ ages were calcu- 
lated according to Mook and van der Plicht (1999) by correcting the isotopic fractionation with $\delta^{13} \mathrm{C}$, calculated from the measurement of the ${ }^{13} \mathrm{C} /{ }^{12} \mathrm{C}$ ratio on ARTEMIS. The standard deviation takes into account the statistical error, the variability of the results, and the background signal. The remaining samples were analyzed at the NSF-Arizona AMS Laboratory, where the $\delta^{13} \mathrm{C}$ and the ratio $\left(F={ }_{\mathrm{ASN}} / \mathrm{A}_{0 \mathrm{~N}}\right)$ between the normalized activity of the sample $\left({ }_{\mathrm{ASN}}\right)$ and the normalized oxalic acid activity $\left(\mathrm{A}_{0 \mathrm{~N}}\right)$ for each sample was measured and used to calculate ${ }^{14} \mathrm{C}$ ages, expressed in ${ }^{14} \mathrm{C}$ yr before present (BP). The reservoir effect $R$ was calculated from the difference between the conventional ${ }^{14} \mathrm{C}$ age and the atmospheric age interpolated to the nearest year from the IntCal04 calibration data set (Reimer et al. 2004). $\Delta \mathrm{R}$ values were calculated from the difference in the conventional ${ }^{14} \mathrm{C}$ age and the Marine04 calibration data set (Hughen et al. 2004), which was interpolated to the year of the shell growth.

\section{RESULTS AND DISCUSSION}

The calculated marine ${ }^{14} \mathrm{C}$ reservoir ages, $\mathrm{R}(\mathrm{t})$, and regional $\Delta \mathrm{R}$ values for mollusks from Senegalese sites are presented in Table 1 as conventional ${ }^{14} \mathrm{C}$ ages (Stuiver and Polach 1977), along with $R$ and $\Delta \mathrm{R}$ values (Stuiver et al. 1986). Marine mollusks, collected alive from Senegalese coastal sites between $\mathrm{AD} 1937-1945$, yielded AMS ${ }^{14} \mathrm{C}$ ages with ages ranging from $530 \pm 60$ to $764 \pm 39{ }^{14} \mathrm{C} \mathrm{yr}$ BP (see Table 1). (Gif-12173 was analyzed by the $\beta$ proportional counter at Gif sur Yvette: $\delta^{13} \mathrm{C}=-$ $0.7 \%$ and $\Delta{ }^{14} \mathrm{C}=-91 \%$.) The weighted average ${ }^{14} \mathrm{C}$ age of the samples is $506 \pm 44 \mathrm{BP}$, while the $\mathrm{R}(\mathrm{t})$ values range from $393 \pm 58$ to $618 \pm 47 \mathrm{BP}$ and the $\Delta \mathrm{R}$ values range from $82 \pm 83$ to $297 \pm 55$ $\mathrm{BP}$. The weighted mean of the reservoir effect $R$ is $511 \pm 50 \mathrm{BP}$, and the weighted mean $\Delta \mathrm{R}$ is $176 \pm$ $15 \mathrm{BP}$. Along with the Gif AMS measurements, the $\Delta^{14} \mathrm{C}$ and the corresponding pMC values are given for each sample.

Table 2 gives the weighted mean of $\mathrm{R}(\mathrm{t})$ and $\Delta \mathrm{R}(\mathrm{t})$ for Mauritanian sites, respectively, $421 \pm 15$ and $71 \pm 13$ BP. The statistical analysis applied for the calculations follows Bevington (1969) and Bevington and Robinson (1982:38-50).

For the Senegalese sites, the calculated mean value of $R(511 \pm 50 \mathrm{BP})$ is higher than the average ocean value of 400 BP (Stuiver and Braziunas 1993). This variation is significant. The rather high reservoir age values for northern Senegal could be explained by the unique oceanographic conditions in this area. The development of upwelling zones on the continent shelf are tightly linked to the action of winds resulting from the anticyclones in the area. The intensity of the upwelling is modulated by the force and the direction of the winds, but also by the topography on the coast and the continental shelf and by surrounding oceanic characteristics.

The upwelling zones are spatially very heterogeneous, with structures such as the separation front between the coastal waters and the warm waters located further from the coast. These zones have a major role in the coupling between physical and biological processes.

At these latitudes, there are 2 major circulations: the Canarias current and the equatorial countercurrent, which transport eastward the warm, salty waters existing in the southern part of the North Atlantic vortex. These systems are divided by a divergence zone, resulting by a development of a crest at the thermocline. Seasonal oscillations in location and intensity are observed, with an average ridge oscillation range of $7^{\circ} \mathrm{N}$ (in winter) to $14^{\circ} \mathrm{N}$ (in summer) in the east Atlantic.

Studies on the hydrology and dynamics of the waters of the Senegalese continental shelf (see Rebert 1982) show the complexity of the physical mechanisms governing the evolution of marine waters near the Senegalese shore. This region's dynamics are thus the most notable for the entire west African coast, with a surface thermal oscillation amplitude of $12{ }^{\circ} \mathrm{C}$. 


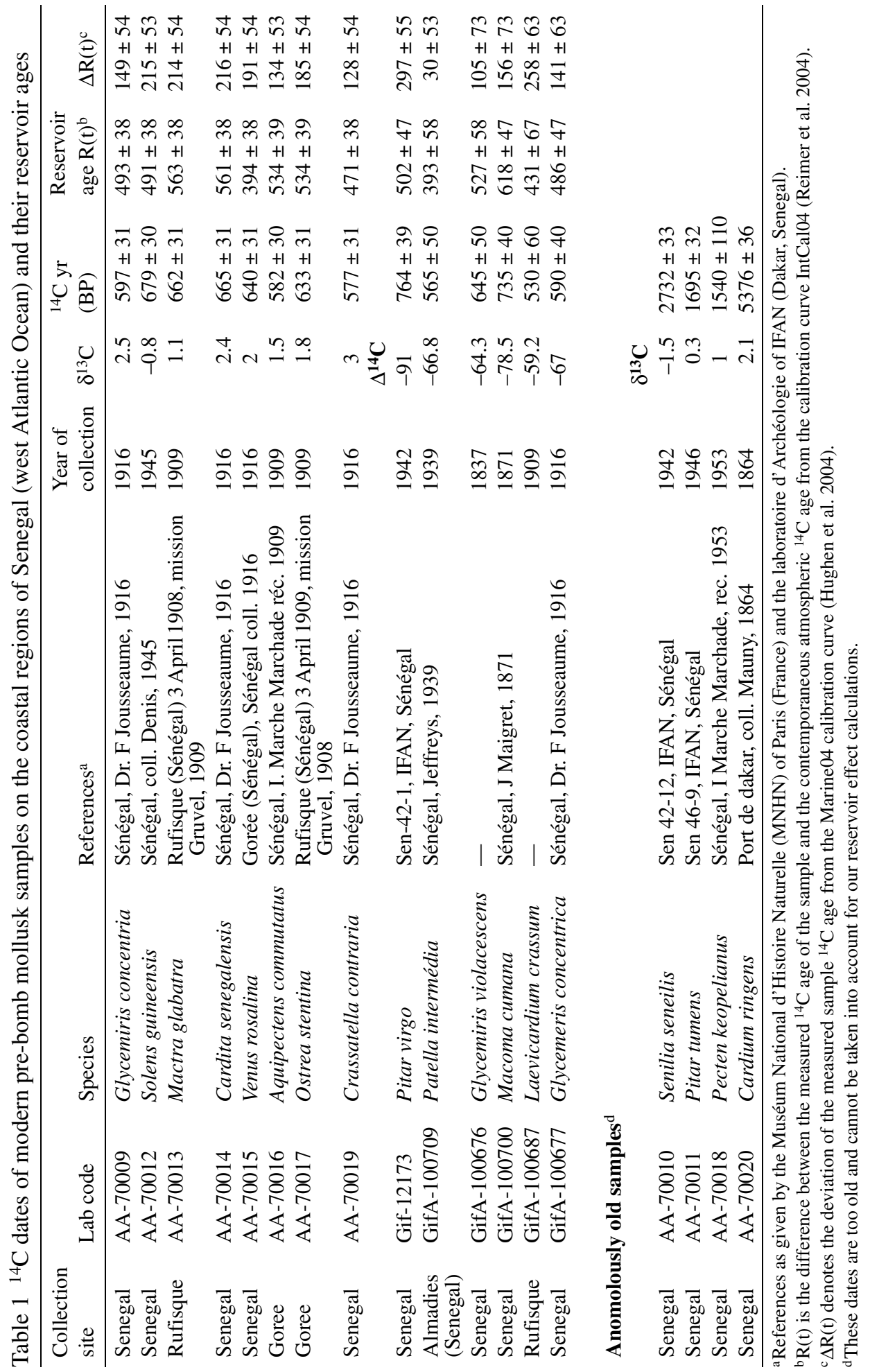




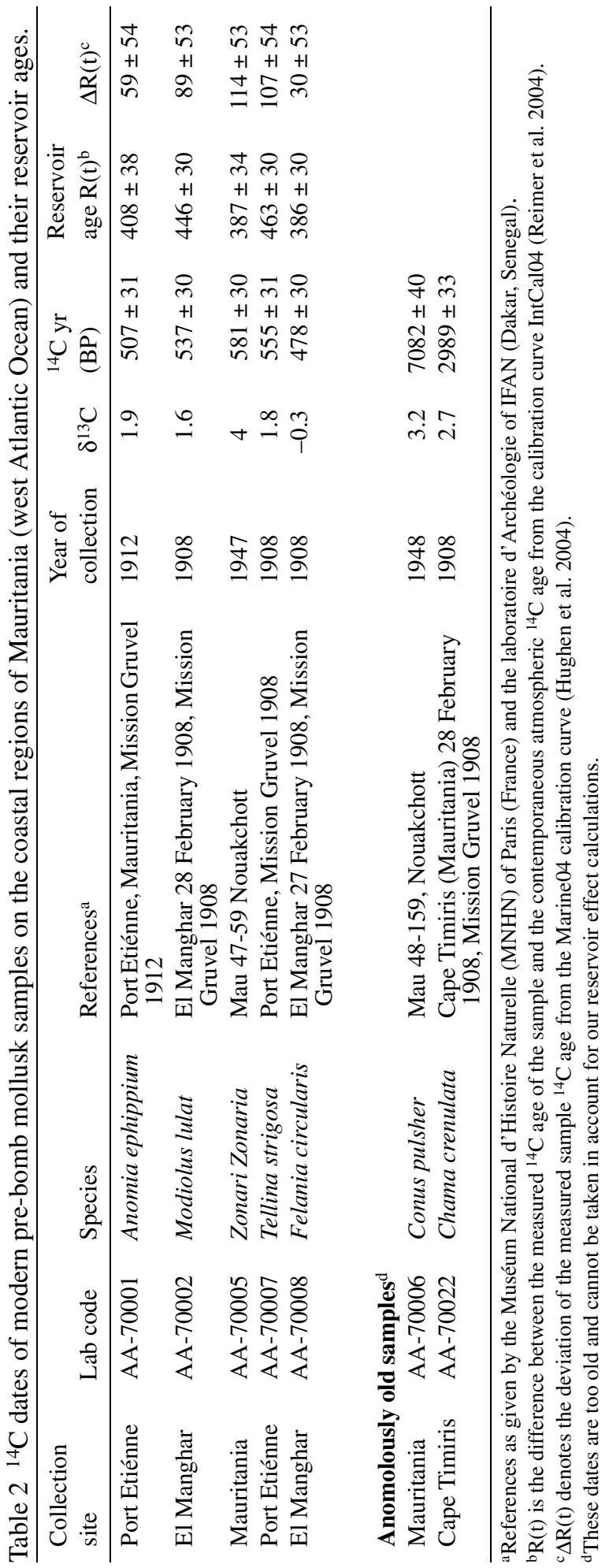


Strong vertical movements develop in the ocean and lead to a constant supply of cold water to the surface. These upwellings, which are mainly due to the winds, shift surface waters away from the shore. However, this process does not occur in a regular manner due to the topography of the continental shelf and coastline, which induce important modifications of the location and the speed of the upwelling. There is a notable coastal upwelling at $16^{\circ} \mathrm{N}$ (city of St-Louis) with a maximum effect in February through April. From February to May, a strong upwelling is also observed north of Dakar (city of Kayar). This upwelling spans to the continental shelf with circulation cells towards the middle of the plateau. On the other hand, on a larger scale the upwelling is partially self-fed, as the appearance/disappearance of the cold waters-tradewinds system is instantaneous and simultaneous.

The hydrological system of the Mauritanian coastal region is subject to the influence of the Canaries current to the north, the Guinean current to the south, and also by continental tradewinds. We observe an important upwelling north of Cape Blanc, where it is quasi-permanent, and south of Cape Timiris (Rebert 1977), with a maximum in May-June and some water stratification. The area known in French as "Banc d' Arguin" covers most of the continental shelf and is characterized by shallow waters. Recent studies on its hydrogeology (Dobrovine et al. 1991; Ould Dedah 1993) show 3 water masses (defined by their surface water temperature and salinity or SST; see Figure 2). During the cold season, the waters from the Cape Blanc to the top of the Banc d'Arguin are subjected to an upwelling. A second water mass located from the edge of the continental shelf $\left(20^{\circ} 10^{\prime} \mathrm{N}\right)$ to Cape Timiris is composed of the transported water of the Canarias stream. The third water mass is located from the Banc d'Aguin to Cape Timiris and corresponds to the coastal waters. During the hot season, the second water mass falls under the influence of the Guinean current.

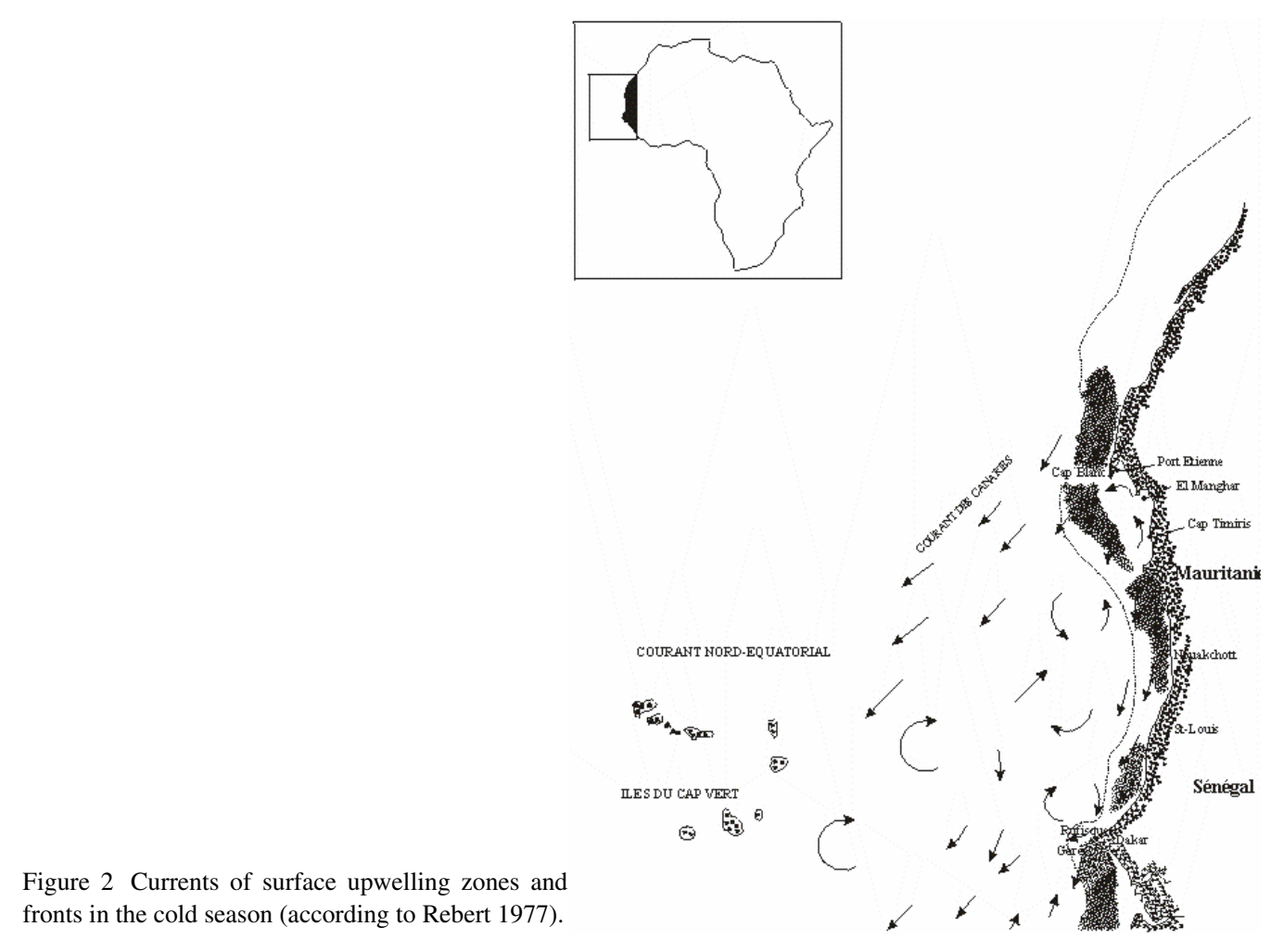


At this point, one wonders if measurement of the reservoir effect is sensitive enough to allow for the differentiation of the above water masses. Prior studies permit us to predict that the reservoir effect is higher than $600 \mathrm{BP}$ for Cape Blanc and Cape Timiris. However, for the coastal waters between these 2 sites and in the central part of Banc d'Arguin, the reservoir effect is not well known. Our calculations show that the mean value of the reservoir effect $(420 \pm 15 \mathrm{BP})$ is close to the worldwide estimate of $400 \mathrm{yr}$ (Stuiver and Braziunas 1993). In these coastal zones, small coastal counter-currents can develop (Rebert 1977) due to thermohaline processes, and in a weak upwelling period, the northern coastal counter-currents occur due to the warming of waters south of the Cape Verde islands. We could thus expect to find this mean reservoir effect of $420 \pm 15 \mathrm{BP}$, which is close to the global mean value. However, a wider sampling thorough the entire Banc d'Arguin region is necessary for an accurate characterization of the reservoir effect.

\section{CONCLUSIONS}

The results presented in Tables 1 and 2 allow us to estimate, provisionally, the ${ }^{14} \mathrm{C}$ reservoir correction values for coastal northern Senegal $(511 \pm 50 \mathrm{BP})$ and for coastal Mauritania (421 $\pm 15 \mathrm{BP})$. The $R$ value for Mauritania in the Banc d'Arguin region is close to the average ocean $R$ value of $\sim 400 \mathrm{yr}$ (Stuiver and Braziunas 1993). A difference from the mean value of $111 \mathrm{BP}$ is observed for the reservoir effect in northern Senegal (from St-Louis to Dakar). The $\Delta \mathrm{R}$ values are $176 \pm 15 \mathrm{BP}$ for Senegal and $71 \pm 13 \mathrm{BP}$ for Mauritania. However, a wider sampling throughout the entire coastal region of northern Senegal and Mauritania is necessary for a more accurate characterization of the reservoir effect.

\section{ACKNOWLEDGMENTS}

I am grateful to Bernard Métivier (Muséum National d'histoire Naturelle, URA 699-CNRS, 75005 Paris, France) and to Ibrahima Thiaw (Laboratoire d'Archéologie de IFAN-UCAD) for providing shells from their collection. I am grateful to the team of the LSCE of Gif sur Yvette in Paris. I am also indebted to Nadine and Claudet (LSCE of Gif sur Yvette) for their technical assistance, and to Evelyne Cottereau (Laboratoire de Mesure du Carbone 14) for helping with the analysis of some of the samples. My thanks go also to J F Saliège (LOCEAN of Université Paris VI) and A J Timothy Jull and G S Burr (NSF-Arizona AMS Facility, Tucson, USA) and to 2 anonymous reviewers for their valuable assistance and comments on this study. However, I alone assume all errors and imperfections that may still be present in the paper.

\section{REFERENCES}

Bevington P. 1969. Data Reduction and Error Analysis for the Physical Sciences. New York: McGraw-Hill. $320 \mathrm{p}$.

Bevington P, Robinson DK. 1992. Data Reduction and Error Analysis for the Physical Sciences. 2nd edition. New York: McGraw-Hill. 328 p.

Dobrovine B, Mahfoud M, Ould Dedah S. 1991. Atlas hydrologique des eaux superficielles du Banc d'Arguin. Nouadhibou: Bulletin du centre national de recherches océanographiques et de pêches. Volume 24. In French.

Goodfriend GA, Flessa KW. 1997. Radiocarbon reservoir ages in the Gulf of California: roles of upwelling and flow from the Colorado River. Radiocarbon 39(2):139-48.
Hughen KA, Baillie MGL, Bard E, Beck JW, Bertrand CJH, Blackwell PG, Buck CE, Burr GS, Cutler KB, Damon PE, Edwards RL, Fairbanks RG, Friedrich M, Guilderson TP, Kromer B, McCormac G, Manning S, Bronk Ramsey C, Reimer PJ, Reimer RW, Remmele S, Southon JR, Stuiver M, Talamo S, Taylor FW, van der Plicht J, Weyhenmeyer CE. 2004. Marine04 marine radiocarbon age calibration, 0-26 kyr BP. Radiocarbon 46(3):1059-86.

Mook WG, van der Plicht J. 1999. Reporting ${ }^{14} \mathrm{C}$ activities and concentrations. Radiocarbon 41(3):227-39.

Ould Dedah S. 1993. Wind, surface water temperature, surface salinity and pollution in the area of the Banc d'Arguin, Mauritania. Hydrobiologia 258(1-3):9-19.

Rebert JP. 1977. Annexe 9: Aperçu de l'hydrologie du 
plateau continental de la Mauritanie à la Guinée [WWW document]. http://www.fao.org/DOCREP/ 003/N0952E/n0952e0n.htm. Accessed 21 March 2005. In French.

Rebert JP. 1982. Hydrologie et dynamique des eaux du plateau continental Sénégalais. Document Scientifique. Centre de Recherches Oceanographiques de Dakar-Thiaroye (Senegal), no. 89. p 26-42. In French.

Reimer PJ, Reimer RW. 2001. A marine reservoir correction database and on-line interface. Radiocarbon 43(2A):461-3.

Reimer PJ, Reimer RW. 2006. Marine reservoir corrections and the calibration curve. PAGES [Past Global Changes] News 14(3):9-10.

Reimer PJ, Baillie MGL, Bard E, Bayliss A, Beck JW, Bertrand CJH, Blackwell PG, Buck CE, Burr GS, Cutler KB, Damon PE, Edwards RL, Fairbanks RG, Friedrich M, Guilderson TP, Hogg AG, Hughen KA, Kromer B, McCormac G, Manning S, Bronk Ramsey C, Reimer RW, Remmele S, Southon JR, Stuiver M, Talamo S, Taylor FW, van der Plicht J, Weyhenmeyer CE. 2004. IntCal04 terrestrial radiocarbon age calibration, 0-26 cal kyr BP. Radiocarbon 46(3):1029-58.
Siani G, Paterne M, Arnold M, Bard E, Métivier B, Tisnerat N, Bassinot F. 2000. Radiocarbon reservoir ages in the Mediterranean Sea and Black Sea. Radiocarbon 42(2):271-80.

Southon J, Kashgarian M, Fontugne M, Métivier B, Yim WW-S. 2002. Marine reservoir corrections for the Indian Ocean and Southeast Asia. Radiocarbon 44(1): 167-80.

Stuiver M, Braziunas TF. 1993. Modeling atmospheric ${ }^{14} \mathrm{C}$ influences and ${ }^{14} \mathrm{C}$ ages of marine samples to 10,000 BC. Radiocarbon 35(1):137-89.

Stuiver M, Polach HA. 1977. Discussion: reporting of ${ }^{14} \mathrm{C}$ data. Radiocarbon 19(3):355-63.

Stuiver M, Pearson GW, Braziunas TF. 1986. Radiocarbon age calibration of marine samples back to 9000 cal yr BP. Radiocarbon 28(2B):980-1021.

Yoneda M, Kitagawa H, van der Plicht J, Uchida M, Tanaka A, Uehiro T, Shibata Y, Morita M, Ohno T. 2000. Pre-bomb marine reservoir ages in the western North Pacific: preliminary result on the Kyoto University collection. Nuclear Instruments and Methods in Physics Research B 172(1-4):377-81. 